\section{PERAN OTORITAS JASA KEUANGAN DALAM MELAKUKAN PENGAWASAN DAN PENCEGAHAN TERHADAP PENDIRIAN PERUSAHAAN INVESTASI ILEGAL DI TINJAU DARI UNDANG-UNDANG NOMOR 21 TAHUN $2011^{1}$}

Oleh: Fallahudin Tsauki Takalamingan ${ }^{2}$

Abdurrahman Konoras ${ }^{3}$

Frietje Rumimpunu ${ }^{4}$

\begin{abstract}
ABSTRAK
Tujuan dilakukannya penelitian ini adalah untuk mengetahui bagaimana, tugas, fungsi, dan Kewenangan Otoritas Jasa Keuangan Menurut Undang-undang Nomor 21 Tahun 2011 dan bagaimana, peranan OJK dalam melakukan pengawasan dan pencegahan terhadap pendirian perusahaan investasi ilegal menurut Undang-undang Nomor 21 Tahun 2011. Dengan menggunakan metode penelitian yuridis normatif, disimpulkan: 1. Otoritas Jasa Keuangan (OJK), Adalah merupakan satusatunya lembaga yang memiliki fungsi, tugas, dan wewenang, dalam melakukan pengaturan dan pengawasan terhadap seluruh lembaga jasa keungan di Indonesia. Kekuatan OJK yang di atur dalam Undang-undang No 21 Tahun 2011, yaitu sebagai lembaga yang memiliki keuatan mengatur (power to regulate) dan mengawasi (power to control), selain menjadikan OJK sebagai lembaga dengan wewenang yang sangat besar, hal ini juga menjadikan OJK sebagai lembaga yang memiliki tugas dan, tanggung jawab yang sangat banyak, sehingga tidak sedikit Lembaga Jasa Keuangan yang kurang mendapat pengawasan oleh OJK. $\mathrm{Hal}$ ini mengakibatkan kesempatan atau peluang Lembaga Jasa Keuangan dalam melakukan kejahatan ekonomi menjadi sangat besar. 2. Peran pengawasan dan pencegahan yang di lakukan OJK terhadap imvestai ilegal, mulai dari pembentukan SWI (Satgas Waspada Investasi), sampai dengan beberapa Peran preventif dan represif lainnya, sudah memberikan dampak positif bagi kegiatan investasi di Indonesia, tetapi hal ini juga bukan berarti peran OJK ini berhasil secara penuh,

\footnotetext{
${ }^{1}$ Artikel Skripsi

2 Mahasiswa pada Fakultas Hukum Unsrat, NIM. 16071101019

3 Fakultas Hukum Unsrat, Doktor Ilmu Hukum
}

${ }^{4}$ Fakultas Hukum Unsrat, Magister IImu Hukum
\end{abstract}

sampai sekarang masi ada saja perusahaan investasi illegal atau kegiatan investasi illegal yang berhasil lolos dari pengawasan OJK. Hal ini dikarenakan implementasi kegiata-kegiatan OJK dalam masyarakat belum sepenuhnya berjalan dengan baik. Pemberian informasi terhadap masyarakat melalui sosialisai, masih minim di lakukan oleh OJK, dan juga pemberian sanksi bagi para pelaku investasi ilegas terbilang sangat ringan, sehingga tidak memberikan efek jera bagi para pelaku kejahatan investasi.

Kata kunci: Peran otoritas Jasa Keuangan, Pengawasan Dan Pencegahan, Pendirian Perusahaan Investasi llegal.

\section{PENDAHULUAN}

\section{A. Latar Belakang}

Investasi merupakan bagian dalam kegiatan ekonomi. Investasi dapat diartikan sebagai suatu kegiatan penanaman modal yang di lakukan oleh investor, baik investor asing maupun domestic dalam berbagai bidang usaha yang terbuka untuk investasi, dengan tujuan untuk memperoleh keuntungan. Investasi di bagi menjadi dua macam, yaitu investasi asing dan domestic. Investasi asing merupakan investasi yang bersumber dari pembiayaan luar negeri. Sementara itu investasi domestic merupakan investasi yang bersumber dari pembiayaan dalam negeri. Investasi itu digunakan untuk pengembangan usaha yang terbuka untuk investasi dan tujuannya untuk memperoleh keuntungan. ${ }^{5}$

Sebagai Negara yang tak terlepas dari kegiatan ekonomi, kita juga tak bisa lepas dari kegiatan Investasi, salah satunya adalah kegiatan Investasi yang di lakukan oleh perusahaan Investasi. Kegiatan-kegiatan investasi yang dilakukan oleh perusahaan banyak kita temukan dalam masyarakat. Namun tak jarang juga djumpai investasiinvestasi illegal atau sering kita sebut sebagai investasi bodong yang berpraktek ditengahtengah masyarakat. Ivestasi illegal secara sederhana diartikan sebagai kegiatan ekonomi yang dalam hal investasi yang melanggar peraturan perundang-undangan. Berdasarkan data yang diambil dari Kumparan.com, menyebutkan bahwa Hingga pertengahan Maret 2020, Otoritas Jasa Keuangan (OJK)

5 Salim HS dan Budi sutrisno, 2008, Hukum Investasi Di Indonesia, Jakarta : PT. Grafindo Persada, HIm. 33 
melalui Satgas Waspada Investasi (SWI) telah menemukan 388 entitas fintech peer to peer (P2P) lending ilegal. Sebelumnya, Januari 2020, SWI menemukan 120 entitas ilegal yang tidak terdaftar di OJK. Sehingga, total sejak Januari 2020 sampai Maret 2020, fintech lending ilegal yang ditemukan mencapai 508 entitas. Sementara, total fintech lending ilegal yang telah ditangani Satgas Waspada Investasi sejak tahun 2018 sampai Maret 2020 sebanyak 2.406 entitas. $^{6}$

Tanpa adanya izin terlebih dahulu oleh Otoritas Jasa Keuangan sebagai lembaga tinggi dalam pengaturan dan pengawasan sektor jasa keuangan Kegiatan Investasi Illegal dilakukan dengan cara melakukan penghimpunan dana masyarakat luas dengan menyimpang bahkan menghindari dari aturan perbankan, merupakan kegiatan yang menggunakan fasilitas publik untuk menjalankan kegiatan usahanya. Dengan demikian perlu dilihat kewenangan yang dimiliki Otoritas Jasa Keuangan dalam memberikan perlindungan bagi masyarakat terhadap kegiatan Investasi Illegal, praktik moral hazard pada kegiatan Investasi Illegal terjadi karena lemahnya sistem pengawasan lembaga keuangan yang disebabkan beberapa faktor, yaitu : (a) lemahnya sistem arsitektur pengawasan keuangan di Indonesia; (b) tidak adanya pertukaran informasi antar lembaga pengawasan keuangan; (c) masih tingginya egosentris antar lembaga pengawas lembaga keuangan.

Berdasarkan uraian latar belakang tersebut penulis tertarik menulis skripsi ini dengan mengangkat judul : "Peranan Otoritas Jasa Keuangan Dalam Melakukan Pengawasan dan Pencegahan Terhadap Pendirian Perusahaan Investasi llegal Ditinjau Dari Undang-Undang Nomor 21 Tahun 2011".

\section{B. Rumusan Masalah}

1. Bagaimana, tugas, fungsi, dan Kewenangan Otoritas Jasa Keuangan Menurut Undang-undang Nomor 21 Tahun 2011 ?

\footnotetext{
${ }^{6}$ https://kumparan.com/kumparanbisnis/temuan-ojk-permaret-15-investasi-bodong-388-fintech-dan-25pegadaian-ilegal-1t2EfLib6bY diakses pada 16 April 2020, Pukul : 21.59 Wita
}

2. Bagaimana, peranan OJK dalam melakukan pengawasan dan pencegahan terhadap pendirian perusahaan investasi ilegal menurut Undang-undang Nomor 21 Tahun 2011 ?

\section{Metode Penulisan}

Ruang lingkup penelitian ini ialah pada disiplin ilmu hukum, maka penelitian ini merupakan bagian dari penelitian hukum kepustakaan yakni dengan "cara meneliti bahan pustaka atau yang dinamakan penelitian hukum normatif'. ${ }^{7}$ Penelitian hukum ada 7 jenis dari perspektif tujuannya, yakni mencakup penelitian inventarisasi hukum positif, penelitian asas-asas hukum, penelitian hukum klinis, penelitian hukum yang mengkaji sistematika peraturan perundang-undangan, penelitian yang ingin menelaah sinkronisasi suatu peratruran perundang-undangan, dan penelitian sejarah hukum. ${ }^{8}$ Jenis penelitian dalam penelitian ini yaitu bersifat normatif, atau disebut juga dengan penelitian normatif. Menurut soerjono Soekanto dan Sri Mamudji yang dikutip oleh Bachrul Amiq bahwa penelitian normatif ialah suatu penelitian yang mengutamakan pengkajian terhadap ketentuan-ketentuan hukum positif maupun asas-asas hukum. Penelitian hukum normatif merupakan penelitian dengan mendasarkan pada bahan hukum baik primer maupun sekunder.

\section{PEMBAHASAN}

A. Fungsi, Tugas, dan Kewenangan Otoritas Jasa Keuangan Menurut Undang-undang Nomor 21 Tahun 2011

Undang- undang Nomor 21 Tahun 2011 tentang Otoritas Jasa keuangan merupakan payung hukum atau landasan hukum berdirinya Otoritas Jasa Keuangan atau OJK dalam melakukan kerjanya. Berdasarkan UndangUndang tersebut maka ditetapkan tujuan dibentuknya OJK secara eksplisit disebutkan dalam Pasal 4 bahwa dibentuknya OJK agar keseluruhan kegiatan di dalam sector jasa keungan : ${ }^{9}$

\footnotetext{
7 Soerjono Soekanto dan Sri Mamudji 2004., Penelitian Hukum Normatif Suatu Tinjauan Singkat., Jakarta, HIm 14.

8 Amirudin dan Zainal Asikin., 2004, Pengantar Metode Penelitian Hukum., Jakarta, HIm 120-132.

${ }^{9}$ Abdurrahman Konoras, Op.Cit, HIm. 46
} 
1. Terselenggaranya secara teratur, adil, transparan dan akuntabel;

2. Mampu mewujudkan system keuangan yang tumbuh secara berkelanjutan dan stabil; dan

3. Mampu melindungi kepentingan konsumen dan masyarakat.

Tujuan otoritas jasa keuangan yang pertama, yakni agar keseluruhan kegiatan didalam sector jasa keuangan terselenggara secara teratur adil transparan dan akuntabel merupakan asas-asas yang terkandung dalam substansi hukum OJK. Asas-asas tersebut ditemukan lebih lanjut dalam penjelasan umum atas Undang-Undang Nomor 21 Tahun 2011, sebagai berikut :

1. Asas Independensi, yakni independen dalam pengambilan keputusan dan pelaksanaan fungsi tugas dan wewenang OJK. Dengan tetap sesuai dengan peraturan perundang-undangan yang berlaku.

2. Asas kepastian hukum, yakni asas dalam Negara hukum yang mengutamakan landasan peraturan perundangundangan dan keadilan dalam setiap kebijakan penyelenggaraan OJK.

3. Asas kepentingan umum, yakni asas yang membela dan melindungi kepentingan konsumen dan masyarakat serta memajukan kesejahteraan umum.

4. Asas keterbukaan, yakni asas yang membuka diri terhadap hak masyarakat untuk memperoleh informasi yang benar jujur dan tidak diskriminatif tentang penyelenggaraan OJK dengan tetap memperhatikan perlingungan atas hak asasi pribadi dan golongan serta rahasia Negara termasuk rahasia sebagaimana ditetapkan dalam peraturan perundangundangan.

5. Asas profesionalitas, yakni asas yang mengutamakan keahlian dalam pelaksanaan tugas dan wewenang OJK dengan tetap berlandasakan pada kode etik dan ketentuan peraturan perundangundangan.

6. Asas integritas, yakni asas yang berpegang teguh pada nilai-nilai moral dalam setiap tindakan dan keputusan yang diambil dalam penyelenggaraan OJK.
7. Asas akuntabilitas, yakni asas yang menetukan bahwa setiap kegiatan Dan hasil akhir dari setiap kegiatan penyelenggaraan OJK harus dapat dipertanggungjawabkan kepada public. ${ }^{10}$

Untuk mencapai tujuan Otoritas Jasa keuangan Undang-Undang Nomor 21 Tahun 2011 telah mengatur pula terkait tugas, fungsi dan wewenang OJK terlebih khusus dalam bidang pencegaha dan pengawasan terhadap pendirian perusahaan invesatasi ilegal, yang akan dijabarkan sebagai berikut :

\section{Fungsi Otoritas Jasa Keuangan (OJK).}

Undang-Undang Nomor 21 Tahun 2011 dalam Pasal 5 menyebutkan bahwa OJK berfungsi menyelenggarakan system pengaturan dan pengawasan yang terintegrasi terhadap keseluruhan kegiatan didalam sector jasa keuangan. ${ }^{11}$

Fungsi OJK tersebut bertolak dari sistem integrasi terhadap keseluruhan kegiatan didalam sector jasa keuangan melalui pengaturan dan pengawasan. Ruang lingkup OJK yang mencakup banyak bidang yang juga disebut sebagai sub system atau sub sector seperti perbankan, perasuransian, investasi dan lain-lainnya membutuhkan tata kendali yang terpusat untuk terintegrasinya aspek hukum dan kebijakan penyelenggaraan fungsi OJK. ${ }^{12}$

\section{Tugas Otoritas Jasa Keuangan (OJK).}

Tugas secara umum OJK dalam UndangUndang Nomor 21 Tahun 2011 disebutkan pada Pasal 6 bahwa OJK yakni melaksanakan tugas pengaturan dan pengawasan terhadap :

a. Kegiatan jasa keuangan disektor perbankan;

b. Kegiatan jasa keuangan disektor pasar modal;

c. Kegiatan jasa keuangan disektor perasuransian, dana pensiun, lembaga pembiayaan dan lembaga jasa keuangan lainnya.

\section{Wewenang Otoritas Jasa Keuangan (OJK).}

Undang-undang Nmor 21 Tahun 2011 menjelaskan tentang kewenangan kewenangan OJK, salah satunya adalah kewengangan OJK

\footnotetext{
10 Ibid, HIm. 46-47

11 Undang-Undang Nomor 21 Tahun 2011

12 Abdurahman Konoras, Op.Cit, HIm. 52
} 
dalam membuat peraturan-peraturan atau ketetapan-ketetapan, sebagai mana tertera pada pasal 8 OJK berwenang ;

a. Menetapkan peraturan pelaksanaan Undang-Undang ini;

b. Menetapkan peraturan perundangundangan di sektor jasa keuangan;

c. Menetapkan peraturan dan keputusan OJK;

d. Menetapkan peraturan mengenai pengawasan di sektor jasa keuangan;

e. Menetapkan kebijakan mengenai pelaksanaan tugas OJK;

f. Menetapkan peraturan mengenai tata cara penetapan perintah tertuli terhadap Lembaga Jasa Keuangan dan pihak tertentu;

g. Menetapkan peraturan mengenai tata cara penetapan pengelola statuter pada Lembaga Jasa Keuangan;

h. Menetapkan struktur organisasi dan infrastruktur, serta mengelola, memelihara, dan menatausahakan kekayaan dan kewajiban; dan

i. Menetapkan peraturan mengenai tata cara pengenaan sanksi sesuai dengan ketentuan peraturan perundangundangan di sektor jasa keuangan. ${ }^{13}$

Huruf (d) pada pasal 8 di atas menjelaskan bahwa OJK mempunyai wewenang membuat aturan-aturan mengenai kegiatan pengwasan yang di lakukan oleh OJK. Dengan demikian kekuatan Hukum OJK dalam melakukan pengawasan terhadap jasa keuangan sangatlah kuat.

Dalam Undang-undang No 21 Tahun 2011 selain mengatur tentang kewenangan membuat peraturan, juga mengatur tentang wewenang OJK dalam melakukan pengawasan di dalam sektor jasa keuangan, yang terdapat dalam pasal 9, yaitu untuk melakukan tugas pengawasan :

a. Menetapkan kebijakan operasional pengawasan terhadap kegiatan jasa keuangan;

b. Mengawasi pelaksanaan tugas pengawasan yang dilaksanakan oleh Kepala Eksekutif c. Melakukan pengawasan, pemeriksaan, penyidikan, perlindungan Konsumen, dan tindakan lain terhadap Lembaga Jasa Keuangan, pelaku, dan/atau penunjang kegiatan jasa keuangan sebagaimana dimaksud dalam peraturan perundangundangan di sektor jasa keuangan;

d. Memberikan perintah tertulis kepada Lembaga Jasa Keuangan dan/atau pihak tertentu

e. Melakukan penunjukan pengelola statuter;

f. Menetapkan penggunaan pengelola statuter;

g. Menetapkan sanksi administratif terhadap pihak yang melakukan pelanggaran terhadap peraturan perundang-undangan di sektor jasa keuangan; dan

h. Memberikan dan/atau mencabut :

1) Izin usaha;

2) Izin orang perseorangan;

3) Efektifnya pernyataan pendaftaran;

4) Surat tanda terdaftar;

5) Persetujuan melakukan kegiatan usaha;

6) Pengesahan;

7) Persetujuan atau penetapan pembubaran; dan

8) Penetapan lain, sebagaimana dimaksud dalam peraturan perundangundangan di sektor jasa keuangan. ${ }^{14}$

B. Peran Otoritas Jasa Keuangan Dalam Melakukan Pengawasan Dan Pencegahan Terhadap Pendirian Perusahaan Investasi llegal menurut Undang-undang Nomor 21 Tahun 2011

Sedangkan kaitanya dengan konsep pencegahan dan pengawasan terhadap pendirian perusahan investasi terlebih khusus bagi investasi illegal atau bodong akan dijabarkan sebagai berikut :

\section{Pembentukan Satuan Tugas Waspada Investasi (SWI) Sebagai Langkah Pengawasan OJK.}

Dalam Undang-Undang Nomor 21 Tahun 2011 tentang OJK, wewenang dan tugas OJK adalah mengawasi lembaga jasa keuangan

\footnotetext{
${ }^{14}$ Undang-undang Nomor 21 Tahun 2011
} 
disektor pasar modal, sector industry keuangan non bank (seperti: asuransi, dana pensiun, perusahaan pembiayaan dll) termasuk mengawasi disektor perbankan. ${ }^{15} \mathrm{Hal}$ itu juga diperkuat dengan ditetapkannya Peraturan Otoritas Jasa Keuangan Nomor 1/POJK.07/2013 Tentang Perlindungan Konsumen Sector Jasa Keuangan. Dimana dalam Pasal 1 angka 3 disebutkan bahwa perlindungan konsumen adalah perlindungan terhadap konsumen dengan cakupan perilaku Pelaku Usaha Jasa Keuangan. ${ }^{16}$ Selanjutnya Dalam bab V pasal 51 dan 52 yang mengatur terkait Pengawasan Perlindungan Konsumen Sektor Jasa Keuangan yang berbunyi : ${ }^{17}$

\section{Pasal 51}

(1) Otoritas jasa keuangan melakukan pengawasan kepatuhan pelaku usaha jasa keuangan terhadap penerapan ketentuan perlindungan konsumen.

(2) Pengawasan sebagaimana di maksud pada ayat (1) meliputi pengawasan secara langsung maupun tidak langsung.

\section{Pasal 52}

(1) Dalam rangka pelaksanaan pengawasan kepatuhan pelaku usaha jasa keuangan terhadap penerapan ketentuan perlindungan konsumen sebagaiman di maksud dalam pasal 51, otoritas jasa keuangan berwenang meminta data dan informasi dari pelaku usaha jasa keuangan berkaitan dengan pelaksanaan ketentuan perlindungan konsumen.

(2) Permintaan data dan informasi sebagaimana di maksud pada ayat (1) dapat di lakukan secara berkala atau sewaktu-waktu apabila di perlukan.

Berdasarkan hal tersebut, OJK melakukan langkah koordinatif antarinstansi untuk mempercepat proses penanganan melalui kerangka kerjasama Satuan Tugas Penangangan Dugaan Tindakan Melawan Hukum di Bidang Penghimpun dana dan Pengelolaan investasi atau yang lebih dikenal dengan Satgas Waspada Investasi. ${ }^{18}$

\footnotetext{
15 Undang-Undang Nomor 21 Tahun 2011

16 POJK Nomor 1/POJK.07/2013

$17 \mathrm{lbid}$

${ }^{18} \mathrm{https} / / /$ www.cnnindonesia.com/ekonomi/20160622083 903-78-140007/pemerintah-deklarasikan-perangmelawan-investasi-bodong? Di akses pada 30 Juli 2020, pukul: 02.19 Wita
}

\section{Peran Preventif Otoritas Jasa Keuangan (OJK).}

Secara umum, preventif dapat diartikan sebagai suatu tindakan yang dilakukan untuk mencegah, mengurangi atau menghilangkan segala kemungkinan yang terjadi atas suatu kejadian yang tidak diinginkan di masa mendatang, yang dapat mengancam diri sendiri ataupun kelompok. Preventif berarti suatu tindakan atau upaya pencegahan. Dalam Kamus Besar Bahasa Indonesia disebutkan bahwa yang dimaksud dengan preventif adalah bersifat mencegah (supaya jangan terjadi apa-apa). Pada prinsipnya, preventif bertujuan untuk meminimalisir adanya suatu keburukan. Biaya yang harus dikeluarkan untuk suatu tindakan preventif lebih murah dibandingkan dengan biaya untuk mengurangi dampak buruk dari suatu peristiwa yang terjadi.

\section{Peran Represif Otoritas Jasa Keuangan}

Represif secara umum dapat diartikan sebagai suatu tindakan aktif yang dilakukan untuk menghentikan suatu penyimpangan yang terjadi. Dalam Kamus Besar Bahasa Indonesia (KBBI) disebutkan bahwa yang dimaksud dengan represif adalah menekan, mengekang, menahan, atau menindas. Dalam pengertian lain represif juga berarti menyembuhkan.

Istilah represif digunakan di banyak bidang. Meskipun pada dasarnya mempunyai arti yang sama, tapi pemakaian istilah represif di bidang yang berbeda mempunyai penjelasan yang berbeda. Pengertian represif dalam aspek hukum merupakan perlindungan akhir berupa sanksi, baik denda atau penjara, serta hukuman tambahan yang bisa diberikan ketika terjadi pelanggaran/perselisihan maupun setelah terjadinya pelanggaran/perselisihan.

Hukum sebagai upaya pemerintah dalam menegakkan keadilan bertujuan untuk menyelesaikan segala permasalahan yang terjadi sebagai akibat dari adanya konflik kepentingan. Pada prinsipnya apapun yang dilakukan oleh pemerintah harus bertumpu dan bersumber pada konsep tentang penegakan keadilan. Hukum represif akan diberlakukan pada saat hukum preventif tidak berhasil dijalankan.

Undang-undang nomor 21 tahun 2011 Pasal 2829 dan 30 mengatur terkait peran preventif 
dan represif Otoritas Jasa Keuangan dalam mencegah dan menindaki putaran perusahan yang berinvestasi illegal. Berdasarkan UndangUndang tersebut langkah represif OJK diantaranya sebagai berikut :

\section{a. Pencabutan izin perusahaan.}

Pasal 28 ayat 2 menyebutkan : meminta lembaga jasa keuangan untuk menghentikan kegiatannya, apabila kegiatan tersebut berpotensi merugikan masyarakat. Selanjutnya disebutkan dalam ayat 3 , yang berbunyi "tindakan lain yang dianggap perlu sesuai dengan ketentuan peraturan perundang-undangan disektor jasa keuangan". ${ }^{19}$

Berdasarkan ketentuan tersbut OJK memiliki wewenang untuk meminta lembaga jasa keuangan untuk menghentikan kegiatannya apabila kegiatan tersebut berpotensi merugikan masyarakat dan melakukan tindakan lain yangdianggap perlu dan sesuai dengan ketentuan peraturan perundang-undangan disektor jasa keuangan. Adanya pasal tersebut merupakan langkah OJK dalam rangka memberikan perlindungan hukum pada tahap represif, yakni dengan meminta lembaga jasa keuangan untuk menghentikan kegiatannya apabila kegiatan tersebut berpotensi dapat merugikan masyarakat, dan melakukan tindakan yang dianggap perlu,penggunaan pasal ini merupakan tindak lanjutdari pengaduan masyarakat sebagai konsumen yang dirugikan atas adanya kegiatan investasi illegal, sehingga perusahaan yang melakukan investasi illegal dapat dicabut izin usahanya dan dapat diberikan sanksi kepada perusahaan yang melakukan investasi ilegal,agar tidak merugikan masyarakat secara luas. ${ }^{20}$ Selain itu, dalam Pasal 53 Peraturan Otoritas Jasa Keunagan Nomor 1/POJK.07/2013 Tentang Perlindungan Konsumen Sector Jasa Keuangan yang mengatur terkait sanksi bagi pelaku jasa keuangan yang melanggar ketentuan yang telah diatur dalam

\footnotetext{
19 Undang-Undang Nomor 21 Tahun 2011

20 file:///C:/Users/Asus/AppData/Local/Temp/1921841078-2-PB.pdf, diakses pada 28 September 2020, Pukul : 01.46 Wita
}

Peraturan itu. Ketentuan tersebut berbunyi

1. Pelaku Usaha Jasa Keuangan dan/atau pihak yang melangar ketentuan dalam Peraturan Otoritas Jasa Keuangan ini dikenakan sanksi administrative antara lain :
a. Peringatan tertulis;
b. Denda yaitu kewajiban untuk membayar sejumlah uang tertentu;
c. Pembatasan kegiatan usaha;
d. pembekuan kegiatan usaha; dan
e. Pencabutan izin kegiatan usaha.

2. Sanksi sebagaimana dimaksud pada ayat (1) hurf b, huruf $c$, huruf $d$ dan huruf e dapat dikenakan dengan atau tanpa didahului pengenaan sanksi peringatan tertulis sebagaimana dimaksud pada ayat (1) huruf a.

3. Sanksi denda sebagaimana dimaksud pada ayat (1) huruf $d$ dapat dikenakan secara tersendiri atau secara bersamasama dengan pengenaan sanksi sebagaimana dimaksud pada ayat (1) hruf $c$, huruf $d$, atau huruf e.

4. Besaran sanksi denda sebagaimana dimaksud pada ayat (1) huruf $b$ ditetapkan Otoritas Jasa Keuangan berdasarkan ketentuan tentang sanksi administrative berupa denda yang berlaku untuk setiap sector jasa keuangan.

5. Otoritas Jasa Keuangan dapat mengumumkan pengenaan sanksi administrative sebagaimana dimaksud pada ayat (1) kepada masyarakat.

b. Membuka pelayanan pengaduan.

Berdasarkan ketentuan Pasal 29 UndangUndang Nomor 21 Tahun 2011 tentang Otoritas Jasa Keuangan, OJK melakukan pelayanan pengaduan Konsumen yang meliputi :21

1. Menyiapkan perangkat yang memadai untuk pelayanan pengaduanKonsumen yang dirugikan oleh pelaku di Lembaga Jasa Keuangan;

2. Membuat mekanisme pengaduan Konsumen yang dirugikan oleh pelaku di Lembaga Jasa Keuangan; dan

\footnotetext{
21 Undang-Undang Nomor 21 Tahun 2011
} 
3. Memfasilitasi penyelesaian pengaduan Konsumen yang dirugikan oleh pelaku di Lembaga Jasa Keuangan sesuai dengan peraturan perundang-undangan di sektor jasa keuangan.

Berdasarkan ketentuan Pasal tersebut, maka apabila terjadi perusahaan yang melakukan kegiatan investasi ilegal dan merugikanmasyarakat, maka Otoritas Jasa Keuangan harus melakukan pelayanan pengaduan masyarakat yangdirugikan atas adanya kegiatan investasi ilegal dengan menyiapkan perangkat,membuat mekanisme pengaduan dan memberikan fasilitas penyelesaian pengaduan masyarakatyang dirugikan oleh perusahaan yang melakukankegiatan investasi ilegal.Sesuai dengan ketentuan Pasal 29 UndangUndnag Nomor 21 Tahun 2011 tentang Otoritas Jasa Keuangan, korban investasi illegal dapat menyampaikan pengaduan yang berindikasikan sengketa antara Pelaku Jasa Keuangan dengan Konsumen (pihak yang dirugikan oleh adanya investasi ilegal) kepada Otoritas Jasa Keuangan. Konsumen dapat melakukan pengaduan atas kerugian yang diterima, kaitannya dengan kegiatan investasi illegal yang melakukan penghimpunan dana dari masyarakat telah merugikan masyarakat luas, pengaduan dapat dilakukan dengan fasilitas yang diberikan OJK melalui peraturan pelaksana Peraturan OJK No.1/D.07/2013 tentang perlindungan konsumen sektor jasa keuangan pada Surat Edaran OJK No 2/SEOJK.07/2014 Tentang Pelayanan \& Penyelesaian Pengaduan Konsumen Pada Pelaku UsahaJasa Keuangan, pengaduan didasarkan atas ungkapan ketidakpuasan nasabah yang disebabkan oleh adanya kerugian akibat adanya kegiatan investasi illegal yang dilakukan oleh suatu perusahaan. Tindak lanjut pengaduan masyarakat kepada OJK dapat dilakukandengan cara penyelesaian pengaduan berupa penyataan maaf atau menawarkanganti rugi kepada masyarakat yang dirugikan sesuai apa yang diatur pada Surat Edaran OJK No 2/SEOJK.07/2014 Tentang Pelayanan \& Penyelesaian Pengaduan Konsumen pada pelaku usaha jasa keuangan, namun melihat investasi illegal merupakan skema yaitu memutar dana masyarakat sebagai perkara ini menjadi yang perlu diatasi.

Berdasarkan hal tersebut, POJK sebagai aturan pelaksana dari Undang-Undang Nomor 21 Tahun 2011 dalam BAB III-nya mengatur terkait Pengaduan Konsumen dan Pemberian Fasilitas Penyelesaian pengaduan oleh OJK yang secara eksplisit disebutkan dalam Pasal 40 sampai Pasal 46 .

c. Penyelesaian sengketa.

Kegiatan transaksi di sektor keuangan mempunyai potensi menimbulkan resiko atau untuk perselisihan di masa depan, sehingga OJK perlu mengatur kewajiban para pelaku di sektor jasa keuangan untuk menyelesaikan pengaduan para konsumen, sebab pada saat menyelesaikan pengaduan para konsumen di lembaga keuangan, seringkali tidak terjadi kesepakatan antara kedua belah pihak dilayanan pengaduan sektor keuangan. Jika konsumen tidak puas dengan penanganan pengaduan, konsumen dapat melanjutkan pengaduan kepengadilan atau Lembaga Penyelesaian Sengketa Alternatif (LAPS). ${ }^{22}$

Peraturan tentang mekanisme penyelesaian sengketa di sector keuangan juga merupakan mandat dari atau implementasi dari Pasal 29 (c) Undangundang No 21 tahun 2011 tentang Otoritas Jasa Keuangan, di mana otoritas Jasa Keuangan di berikan tugas menangani pengaduan dari konsumen yang dirugikan oleh pelaku sector jasa keuangan sesuai dengan hukum dan peraturan yag berlaku. ${ }^{23}$

\section{PENUTUP}

\section{A. Kesimpulan}

1. Otoritas Jasa Keuangan (OJK), Adalah merupakan satu-satunya lembaga yang

\footnotetext{
22 Dian Husna Fadlia dan Yunanto, 2015, Peran Otoritas Jasa Keuangan Dalam Perlindungan Hukum Bagi Investor Atas Dugaan Investasi Fiktif, HIm. 213

${ }^{23} \mathrm{lbid}, \mathrm{HIm} .214$
} 
memiliki fungsi, tugas, dan wewenang, dalam melakukan pengaturan dan pengawasan terhadap seluruh lembaga jasa keungan di Indonesia.

Kekuatan OJK yang di atur dalam Undang-undang No 21 Tahun 2011, yaitu sebagai lembaga yang memiliki keuatan mengatur (power to regulate) dan mengawasi (power to control),selain menjadikan OJK sebagai lembaga dengan wewenang yang sangat besar, hal ini juga menjadikan OJK sebagai lembaga yang memiliki tugas dan, tanggung jawab yang sangat banyak, sehingga tidak sedikit Lembaga Jasa Keuangan yang kurang mendapat pengawasan oleh OJK. Hal ini mengakibatkan kesempatan atau peluang Lembaga Jasa Keuangan dalam melakukan kejahatan ekonomi menjadi sangat besar.

2. Peran pengawasan dan pencegahan yang di lakukan OJK terhadap imvestai ilegal, mulai dari pembentukan SWI (Satgas Waspada Investasi), sampai dengan beberapa Peran preventif dan represif lainnya, sudah memberikan dampak positif bagi kegiatan investasi di Indonesia, tetapi hal ini juga bukan berarti peran OJK ini berhasil secara penuh, sampai sekarang masi ada saja perusahaan investasi illegal atau kegiatan investasi illegal yang berhasil lolos dari pengawasan OJK. Hal ini dikarenakan implementasi kegiata-kegiatan OJK dalam masyarakat belum sepenuhnya berjalan dengan baik. Pemberian informasi terhadap masyarakat melalui sosialisai, masih minim di lakukan oleh OJK, dan juga pemberian sanksi bagi para pelaku investasi ilegas terbilang sangat ringan, sehingga tidak memberikan efek jera bagi para pelaku kejahatan investasi.

\section{B. Saran}

1. Agar terlaksana seluruh kegiatan OJK dengan baik, maka OJK perlu meningkatkan kualitas dan kuantitas dari para pegawai OJK. Selain merekrut pegawai dari BI, dan Bapepam-LK OJK juga harus melakukan Rekrutmen dari Masyarakat, dengan proses rekrutmen yang berkualitas agar mengahasilakan pegawai OJK yang berkualitas pula.

2. Untuk mencegah kejahatan Investasi yang terjadi di masyarakat, maka OJK haarus melakukan peningkatan edukasi, dengan lebih giat lagi memberikan atau melakukan sosialisasi terhadap masyarakat tentang Investasi llegal. Selanjutnya OJK juga harus melakukan peningkatan penegakan Hukum, dengan meningkatkan lagi hubungan kerja sama dengan lembaga penegak hukum lain. Dan juga memperberat sanksi-sanksi bagi pelaku kejahatan Investasi agar dapat memberikan efek jera bagi para pelaku.

\section{DAFTAR PUSTAKA}

Buku

Amirudin, \& Zainal Asikin. (2004). Pengantar Metode Penelitian Hukum. Jakarta.

Ceccato Vania \& Nalla K. Mashesh. (2020). Crime And Fear In Public Places; Toward Safe, Inclusive And Sustainable Cities. Stockholm: Routledge

Fadilah Husna Dian, \& Yunanto. (2015). Peran Otoritas Jasa Keuangan Dalam Perlindungan Hukum Bagi Investor Atas Dugaan Investasi fiktif. Jakarta.

Hadad D Muliaman. (2017). OJK WAY, Implementasi Manajemen perubahan Di OJK. Jakarta: PT. Gramedia WidiaSarana Indonesia.

Hari, B.S Hari., \& M. Husaeni. (1987). Teori Organisasi Suatu Pendekatan Makro. Jakarta: PAU UI.

S H Salim, Dan Budi Sutrisno. (2008). Hukum Investasi DI Indonesia. Jakarta: PT. Raja Grafindo Persada.

Konoras Abdurrahman. (2015). Aspek Hukum Otoritas Jasa Keuangan (OJK) : Teori Dan Praktek Di Indonesia. Makasar: Pustaka Pena Press.

Konoras Abdurrahman. (2020). Hukum Investasi. Manado: Unsrat Press

Noor F Henri. (2009). Investasi Pengelolaan keuangan Bisnis Dan Pengembangan. Jakarta: PT.Indeks. 
Situmorang. (1994). Aspek Hukum Pengawasan Melekat dalam Lingkungan Aparatur Negara. Jakarta.

Soekanto Soerjono \& Sri Mamudji. (2004). Penelitian Hukum Normatif Suatu Tinjauan Singkat. Jakarta.

Soesatro Hadi, DKK. (2005). Pemikiran Dan Permasalahan Ekonomi Di Indonesia Dalam Setengah Abat Terakhir. Jakarta: Kanisius.

Sutedi Adrian. (2014). Aspek Hukum Otoritas Jasa Keuangan. Jakarta: Raih Asa Sukses.

Tjandra Riawan. (2013). Hukum Keuangan Negara. Jakarta : Grasindo.

\section{Sumber-sumber Lain :}

https://situspendidikanpeluangbisnis.wordpres s.com/2019/01/10/perusahaaninvestasi/,

https://kumparan.com/kumparanbisnis/temua n-ojk-per-maret-15-investasibodong-388-fintech-dan-25pegadaian-ilegal-1t2EfLib6bY

https://www.cnnindonesia.com/ekonomi/2016 0622083903-78-

140007/pemerintah-deklarasikanperang-melawan-investasibodong?

https://ajaib.co.id/basmi-investasi-bodong-ojklakukan-pengawasan-ketat/

https://andarurahutomo.blogspot.com/2016/0 7/teori-pencegahan-kejahatansituasional.html,

https://core.ac.uk/download/pdf/11705556.pd $f$,

file://C:/Users/Asus/AppData/Local/Temp/192 18-41078-2-PB.pdf,

Undang-undang No 21 Tahun 2011 Tentang Otoritas Jasa Keuangan

Peraturan Otoritas Jasa Keuangan Nomor 1/POJK.07/2013 Tentang Perlidungan Konsumen Sektor Jasa Keuangan.

Kamus Besar Bahasa Indonesia (KBBI) 